\title{
The Usage of Rogatory Online Monitoring System as a Proof of Advancement in Indonesia's Legal Documentation System
}

\author{
Natasya Fila Rais ${ }^{1 *}$ \\ ${ }^{I}$ Faculty of Law, Universitas Indonesia, Depok, Jawa Barat, Indonesia \\ *Corresponding author.Email: natasya.filarais@gmail.com
}

\begin{abstract}
This article is aimed to introduce its readers to Rogatory Online Monitoring system, a system created by the Ministry of Foreign Affairs of the Republic of Indonesia, under the cooperation of the Supreme Court of the Republic of Indonesia. This system allows the government to track cases that are on the scope of private international law and are required documents that need to be sent from or to other countries. The system itself works as a database and was created to monitor legal documents transfer, especially from other countries. This system was released in 2018 and it received positive reviews for its practice. However, the existence of Rogatory Online Monitoring has not widely known and its benefits have not been socialized much, especially towards those who are in need to settle disputes on private international law. This article comprehensively tells about the history and legal basis of Rogatory Onlline Monitoring System. The article also determines the procedures conducted through Rogatory Online Monitoring system. The implementation of Rogatory Online Monitoring System as a proof of advancement in Indonesia's legal documentation system will also be explained in this article. This article uses normative methodology based on juridical perspectives.
\end{abstract}

Keywords: Indonesia, Law, Ministry of Foreign Affairs, Private International Law, Rogatory Online Monitoring

\section{INTRODUCTION}

\subsection{Background}

As Indonesia is currently reaching Industry 4.0, various sectors are trying their best to advance their systems to cooperate with technology. The legal sector does not miss the chance to enhance its system, aligned with the advancement of technology. One of a few ground-breaking advancement in the law sector which is related to the advancement of technology is the Rogatory Online Monitoring system, also simply known as Rogatory. This system, which can be accessed through its official website, was created under the cooperation of the Ministry of Foreign Affairs of the Republic of Indonesia and the Supreme Court of the Republic of Indonesia. This system, which was released in 2018, allows the government to track private international law cases that are settled or under trial. Aside from that, the system tracks down cases that require documents that need to be sent from or to other countries. Rogatory Online Monitoring system works as a database to monitor legal documents transfer, especially documents that need to be transfer to other countries or foreign legal documents that are needed to be transferred to Indonesia. This system is aimed to simplify the process of foreign legal document transfer, as the practice itself has been growing in number in Indonesia. However, one of the main problems that need to be discussed on the aforementioned system is the lack of publicity of it. This lead to not many people knowing about the existence of the system.

This article, titled The Usage of Rogatory Online Monitoring System as a Proof of Advancement in Indonesia's Legal Documentation System, is aimed to introduce readers to Rogatory Online Monitoring system. This article explains how Rogatory Online Monitoring system was initially created and the legal basis of Rogatory Online Monitoring, both on the national and international scopes. The procedures conducted through Rogatory Online Monitoring will also be explained in the article. The procedures that are explained in this article include procedure of the entrance and transfer of documents, how to check the pricing of document transfer and the procedure of checking on the legal documents that are being transferred or needed to receive. Hopefully, this article will be a source to gain more information on Rogatory Online Monitoring system, so in the future, more people will be aware of the system as well as being able to use the platform wisely. Aside from that, the Author hopes that this article will be able to become one of the sources of knowledge regarding private international law in general and Rogatory Online Monitoring system specifically. Hopefully, this article will become a resource that is able to be used for the advancement of academic world, especially on the topic of law and technology. 


\subsection{Problem Statement}

Based on the background stated above, this paper will discuss several problems, as written below:

1. What are the history and legal basis of Rogatory Online Monitoring System?

2. How are the procedures conducted through Rogatory Online Monitoring System?

3. How is the implementation of Rogatory Online Monitoring System as a proof of advancement in Indonesia's legal documentation system?

\subsection{Aim of Study}

This paper is created for several purposes below, such as:

1. Identifying the history and legal basis of Rogatory Online Monitoring System.

2. Determining the procedures conducted through Rogatory Online Monitoring System.

3. Analyzing the implementation of Rogatory Online Monitoring System as a proof of advancement in Indonesia's legal documentation system.

\subsection{Methodology}

This article uses normative methodology based on juridical perspectives. Normative methodology uses the approach of secondary data, which can be found on several documents, such as books, journal articles, dissertations, acts, international conventions and other written resources which are related to the topic. The Author conducted research on the history and legal basis of Rogatory Online Monitoring system from Rogatory Online Monitoring official website and the Ministry of Foreign Affairs of the Republic of Indonesia official website. The Author also used journal articles and legislations, such as acts, Memorandum of Understanding and international conventions, to complete the research for this paper. As of the procedures conducted through Rogatory Online Monitoring system, the Author conducted her research through academic publications and Rogatory Online Monitoring website, which provided concise information on the procedures. The Author analyzes cases that have happened in order to complete the research for the implementation of Rogatory Monitoring System. The cases occurred in Indonesia and the Author used Indonesia's law instruments in order to base each implementation with positive law.

\section{ANALYSIS}

\subsection{History and Legal Basis of Rogatory Online Monitoring System}

Rogatory, or known as Rogatory letter, is a letter of request sent from one country to another regarding the request of foreign legal document transfer for the purpose of trial procedure, such as for evidence and other supporting steps. Indonesia created an online system which allowed parties and non-parties of disputes to track down the progress of the letters and the document transfer called Rogatory Online Monitoring. Rogatory Online Monitoring system is a database created by Ministry of Foreign Affairs of the Republic of Indonesia, in cooperation with the Supreme Court of the Republic of Indonesia. This program is aimed to advance the development of Indonesia's private international law, in order to solve technical problems between Indonesia and other countries regarding the situation. On February 20th, 2018, the Ministry of Foreign Affairs of the Republic of Indonesia and the Supreme Court of the Republic of Indonesia signed a Memorandum of Understanding (MoU) in regards to the Rogatory Online Monitoring system. The MoU itself was created in order to create simplicity in foreign legal document transfer from and to Indonesia.

During real practice, Indonesian court and courts in other countries cannot communicate directly regarding document transfer process. Therefore, Rogatory Online Monitoring system becomes a bridge between each court. The principle used in this system is how one sovereign country is able to deliver or receive legal documents to or from another sovereign country. These documents are supposedly owned by the government of each country and are under the jurisdiction of each nation. Therefore, diplomatic channel is used to create paths between one sovereign country with another, in regards to the situation. The Ministry of Foreign Affairs of the Republic of Indonesia is a governmental institution which serves as an institution-in-charge of foreign policy and diplomatic issues. On the other hand, the Supreme Court of the Republic of Indonesia is the governmental institution which serves as an institution which is in charge of every court in Indonesia. Both institutions play important role in the creation of this system, as the Ministry becomes the institution that connects each country, while the Supreme Court serves its best purpose in handling legal disputes and documentation in Indonesia. Also signed on the day of the MoU signing were three other agreements, such as agreements regarding letter of requests for submission of documents to requested state submitted by the Court through the Registrar of the Supreme Court, request for help submitting documents which must use document standards and the cost of submitting or sending documents being charged to the litigant and deposited by the court to a holding account in the name of the Registrar's Office of the Supreme Court. 
A few days before Rogatory Online Monitoring release, the Registrar of the Supreme Court, Made Rawa Aryawan, released a guidance on Rogatory letter submission on private law cases. This guidance was written in on the Letter Number 1747/PAN/HK.01/8/2018 dated August 8th, 2018, which was directed to every Chief of Court in Indonesia. A few methods which are explained in the guidance are as follows:

i. The Rogatory letter has to be intended for the Registrar of the Supreme Court and sent to a PO Box address;

ii. The Rogatory letter has to include the number of the agreement letter between the Supreme Court and PT. Pos Indonesia, Indonesia's government-led postal service;

iii. The delivery fee must be sent through a virtual bank account;

iv. The estimation of fee has to be accessed through the Rogatory Online Monitoring application.

The Rogatory Online Monitoring system was finally released on September 10th 2018 by the Vice Minister of Foreign Affairs, Dr. H. M. Fachir, and the Chief of Supreme Court, Prof. Dr. M. Hatta Ali, S.H., M.H. the MoU for this release was signed by Prof. Dr. M. Hatta Ali, S.H., M.H. and the Minister of Foreign Affairs, Her Excellency Retno LP Marsudi. This MoU managed the request of technical legal aid and the request of legal documents to foreign courts. This MoU was created to implement the principles of trial that Indonesia had used in its litigation procedure, which was the Speedy Trial principle. This system was seen as a way to realize the Speedy Trial principle in terms of disputes between parties from Indonesia and other countries. This MoU worked to fill the void in the regulations regarding legal aid in international private law. From the moment, the Rogatory Online Monitoring website (http://rogatori.kemlu.go.id) was able to be accessed publicly.

In terms of the legal basis, the creation of Rogatory Online Monitoring system was based on regulations as follows:

i. Agreement between Ministry of Foreign Affairs of the Republic of Indonesia and the Supreme Court of the Republic of Indonesia Number 909/B/HI/02/2018/01 and Number 02/SKB/MA/2/2018 on the Formation of Technical Private Law Aid Request Management Team;

ii. Memorandum of Understanding between Ministry of Foreign Affairs of the Republic of Indonesia and the Supreme Court of the Republic of Indonesia Number PRJ/HI/102/02/2018//01 and Number 01/NK/MA/2/2018 on the Technical Private Law Aid Request Management;

iii. Convention of 5 October 1961 Abolishing the Requirement of Legalization for Foreign Public Documents; iv. Convention of 15 November 1965 on the Service Abroad of Judicial and Extrajudicial Documents in Civil or Commercial Matters;

v. Convention of 18 March 1970 on the Taking of Evidence Abroad in Civil or Commercial Matters;

vi. Cooperation agreements on document transfer, document standardization, training and curriculum, Rogatory letter delivery from foreign courts, the standardization of received document receipts and Rogatory management standards (2018).

\subsection{Procedures Conducted Through Rogatory Online Monitoring System}

The Rogatory Online Monitoring website includes links to the Supreme Court Verdict Directory and its list of courts all across Indonesia in order to track down private international law cases which require Rogatory letter and transfer of documents. Aside from that, the Rogatory Online Monitoring website provides requirements and steps that are used by foreign countries in terms of document transfer. Not only requirements, the website also provides details on fees that need to be paid for document transfer. For example, the website provides requirements for document transfer from or to Indonesia to or fom Greek. The steps are as follows:

i. Based on the Greek government regulations, all documents must be translated into English and has to be sent to Directorate E3 (Administrative and Court Matters), Ministry of Foreign Affairs of Greek, 6 months before court schedule through diplomatic channel;

ii. Directorate E3 will send court notice which has been translated into English to the Ministry of Justice, Transparency and Human Rights Greek;

iii. The Ministry of Justice, Transparency and Human Rights Greek will translate the notice to Greek and send them to the parties who are in dispute;

iv. It will take 4-5 months of delivery if the parties live around Athena;

v. However, it will take more months if the delivery conducts towards farther regions.

As for the delivery costs, Greek uses guidance of international delivery costs regulated by DHL, an international postal service.

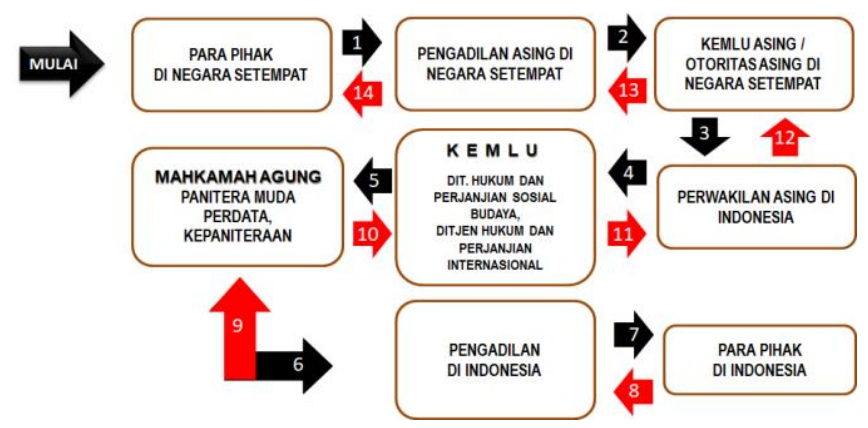

Figure 1.b. Scheme of procedure on document entrance to Indonesia (Source: http://rogatori.kemlu.go.id/flow2) 
Above is the scheme of procedure on document entrance to Indonesia. First, it starts with the parties on the foreign country which files a request to the court in their country. And then, the request will be delivered to the country's Ministry of Foreign Affairs, which will be delivered to the Indonesian representatives in the country. Afterwards, the request will be sent to the Directorate of Socio-Cultural Treaties, Directorate General of Legal Affairs and International Treaties, Ministry of the Republic of Indonesia. The Ministry of Foreign Affairs of the Republic of Indonesia, then, delivered the request to the Private Law Registrar at the Supreme Court. The Supreme Court will deliver the request to the Indonesian court which is in charge of the case, which will deliver the request to the Indonesian parties of dispute. After it is agreed, the agreement notice will be sent back to the parties in the foreign country through the Indonesian court, the Supreme Court, the Ministry of Foreign Affairs of the Republic of Indonesia, the Indonesian Representatives in the foreign country, the Ministry of Foreign Affairs of the foreign country and the foreign court respectively.

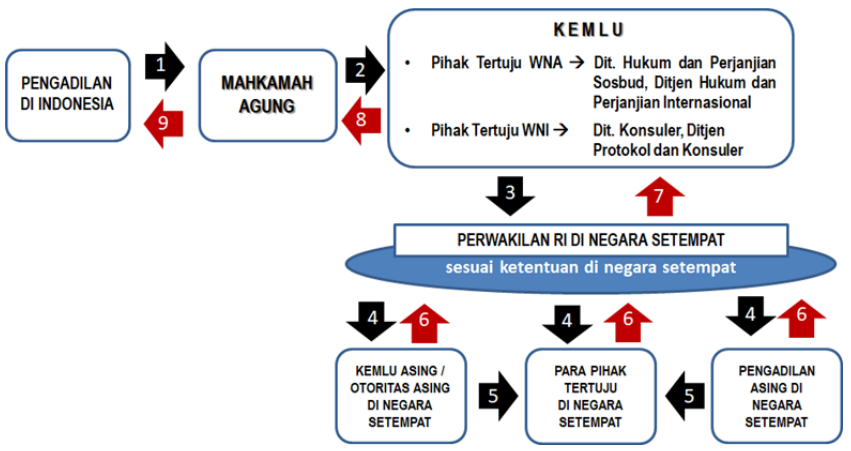

Figure 2.b. Scheme of procedure of document transfer to other countries (Source: http://rogatori.kemlu.go.id/flow1)

The scheme of procedure of document transfer to other countries is described above. The court in Indonesia will send the letters to the Supreme Court. Then, the letters will be sent to the Ministry of Foreign Affairs of the Republic of Indonesia to the parties. if the parties are Indonesian citizens, it will be delivered by the Directorate of SocioCultural Treaties, Directorate General of Legal Affairs and International Treaties, Ministry of the Republic of Indonesia. On the other hand, if the parties are foreign citizens, the letter will be delivered by the Directorate of Consul, Directorate General of Protocol and Consul. Then, the letter will be sent to the Indonesian representatives in the received state, who will deliver the letter to the country's Ministry of Foreign Affairs and the country's court. Then, the letter will be delivered to the parties in the received state. Procedure will be conducted backwards if the letter is sent back to the parties in Indonesia.

Based on the Indonesian regulations, the Rogatory letter must include names of parties, purpose of request, brief description of the dispute, the type of legal aid, names and addresses of witnesses which will be present in the court, questions for witnesses, documents that need to be examined, notice for related institutions, fees and taxes, date of request and signatures. Request of document must include name of parties, addresses of parties and names as well as addresses of witnesses. Both letters must be provided by their own Indonesian translations, unless stated otherwise.

\subsection{Implementation of Rogatory Online Monitoring System as a Proof of Advancement in Indonesia's Legal Documentation System}

Based on the data compiled by the Ministry of Foreign Affairs of the Republic of Indonesia, the Rogatory Online Monitoring system has examined 60 rogatories that have entered Indonesia and 1870 rogatories being sent out of Indonesia. The amount of rogatories accepted by parties are 41 based on the data provided. This proves that the Rogatory Online Monitoring system has been used effectively. Aside from that, from the data being tracked, that means that the system has been used based on the procedure stated on the website and agreements.

Aside from the data of documents being delivered to and from Indonesia, the Indonesian government is also active in raising awareness on the Rogatory Online Monitoring implementation. For example, the socialization programs regarding the Rogatory MoU and the system's procedure were held by Indonesia's representatives in Bangkok, Thailand, on May 7th to 9th, 2018, and Indonesia's representatives on Washington DC, United States of America, on July 18th to 21 st, 2018. These programs were held in a couple of cities that have more Indonesian citizen interactions, in which there were possibilities of Indonesians to have disputes in private international law with nonIndonesian parties in each region.

These programs are proofs that Indonesia is active in promoting Rogatory Online Monitoring system to other countries. These promotions program encourage other countries to also raise awareness on the existence of this system, so that whenever they have to face legal document transfer, they will be able to use the Rogatory system. These promotions programs will also encourage other countries to create similar Rogatory Online Monitoring system. By having similar database system, each country will no longer have to choose other methods that potentially will harm each country's sovereignty. Hopefully, Indonesia is able to become a set of example of the advancement on the legal and technology sectors for the international world.

\section{CONCLUSION}

In conclusion, Rogatory Online Monitoring system has become one of the proofs of advancement in the legal and technology sector in Indonesia. The data-tracking system that is carried out by Rogatory Online Monitoring displays easiness in accessibility. The legal basis for this system also proofs that the program is carried out based on the law. The Rogatory Online Monitoring procedures do not put parties in difficulties. Parties who are in disputes are able to track 
down the documents needed for settlement. According to the data of the system implementation, it is proven that the system has been used multiple times and it has been working effectively. Rogatory Online Monitoring system supports the advancement of technology on the legal sector and is able to connect the society, in regards to data access and transparency of documentation.

\section{REFERENCES}

[1] Ministry of Foreign Affairs Republic of Indonesia. "Ketua MA dan Menlu Sepakat untuk Tingkatkan Pelayanan Publik di Bidang Hukum Perdata." https://www.kemlu.go.id/id/berita/Pages/Ketua-MAdan-Menlu-Sepakati-Kerja-Sama-untuk-TingkatkanPelayanan-Publik.aspx. Accessed April 3rd, 2019.

[2] Ministry of Foreign Affairs Republic of Indonesia. "Proses Pengiriman Surat Rogatori dan Dokumen Perdata Lintas Batas Negara Bisa Dipantau Secara Online."

https://www.kemlu.go.id/id/berita/Pages/SuratRogatori-dan-Dokumen-Perdata.aspx. Accessed April 3rd, 2019.

[3] Ministry of Foreign Affairs Republic of Indonesia. "Statistik Rogatori". http://rogatori.kemlu.go.id/. Accessed April 3rd, 2019.

[4] Nofriandi, Pepy. "MA dan Kemlu Luncurkan Prosedur Baru Penyampaian Dokumen Peradilan Bagi Pihak Berperkara di Luar Negeri." https://www.mahkamahagung.go.id/id/berita/3189/madan-kemlu-luncurkan-prosedur-baru-penyampaiandokumen-peradilan-bagi-pihak-berpekara-di-luarnegeri. Accessed April 3rd, 2019.

[5] Ministry of Foreign Affairs Republic of Indonesia. "Ketentuan Asing: Yunani." http://rogatori.kemlu.go.id/certainty. Accessed April 3rd, 2019.

[6] Savitri, Eva. "MA Gandeng Kemlu Tingkatkan Layanan Hukum Perdata Internasional." https://news.detik.com/berita/d-4435958/ma-gandengkemlu-tingkatkan-layanan-hukum-perdatainternasional. Accessed April 3rd, 2019. 